\title{
Hubungan Tingkat Pendidikan, Akses Informasi dan Dukungan Kader dengan Perilaku Pemeriksaan IVA Pada Wanita Usia Subur (WUS)
}

\author{
Novi Fitriani ${ }^{1}$, Merisa Riski ${ }^{2}$, Putu Lusita ${ }^{3}$, Nati Indriani, \\ Universitas Kader Bangsa Palembang1,2,3,4
}

\section{A B S T R A K}

Informasi Artikel :

Diterima : 01 November 2021

Direvisi : 08 November 2021

Disetujui : 20 Desember 2021

Diterbitkan : 30 Desember 2021

${ }^{*}$ Korespondensi Penulis : fitrianinovi@gmail.com ${ }^{1}$, merisa_rizki@yahoo.com ${ }^{2}$, putu.indriani91@gmail.com ${ }^{3}$.
Kanker serviks dapat dicegah dengan melakukan deteksi dini, salah satunya dengan pemeriksaan IVA. Namun cakupan pemeriksaan IVA di Puskesmas Taman Bacaan masih sangat rendah yaitu $1,74 \%$. Tujuan penelitian ini yaitu untuk mengetahui hubungan tingkat pendidikan, akses informasi, dan dukungan kader dengan perilaku pemeriksaan IVA. Penelitian ini menggunakan metode survey analitik dengan pendekatan cross sectional. Subjek penelitian adalah wanita usia subur yang sudah menikah yaitu sebanyak50 responden. Pengambilan sampel dilakukan dengan cara non random sampling dengan teknik accidental sampling. Instrumen penelitian adalah kuesioner.Perilaku pemeriksaan IVA masih rendah (26\%). Hasil analisa bivariat derajat kepercayaan (CI) 95\% didapatkan hubungan yang signifikan antara tingkat pendidikan ( $p$ value $=0,023)$, akses informasi $($ vvalue $=0,000)$, dan dukungan kader $(p$ value $=0,000)$ dengan perilaku pemeriksaan IVA. Faktor yang paling berpengaruh terhadap perilaku pemeriksaan IVA adalah dukungan kader dengan nilai OR yaitu 57,600. Artinya Wanita Usia Subur (WUS) yang mendapat dukungan kader mempunyai resiko 57,600 kali untuk melakukan pemeriksaan IVA. Terdapat hubungan antara tingkat pendidikan, akses informasi dan dukungan kader dengan perilaku pemeriksaan Inspeksi Visual Asam Asetat (IVA) pada Wanita Usia Subur (WUS) di Puskesmas Taman Bacaan tahun 2021. Disarankan kepada tenaga kesehatan untuk rutin melakukan penyuluhan dan pelatihan kepada kader tentang pemeriksaan IVA

Kata Kunci : IVA, Tingkat Pendidikan, Informasi, Kader 
IVA examination was the cadre support with an OR value of 57.600, which meant that the women of childbearing ages supported by cadres had a risk of 57.600 times to implement the IVA examination. There was a relationship of education level, information access and cadre support with the behavior of Acetic Acid Visual Inspection (AVI) examination in Women of Childbearing Ages at Puskesmas Taman Bacaan in 2021. It is recommended that the health workers should routinely implement the extension and training to the cadres about the IVA examination.

Keywords : Acetic Acid Visual Inspection (IVA), education level, information, cadre.

\section{PENDAHULUAN}

Kanker serviks atau kanker leher rahim merupakan kanker yang menyerang organ reproduksi wanita pada bagian leher rahim/ serviks, bagian ujung/ puncak vagina (Junaidi dan Frisca, 2020). Menurut data United Nations Programme on HIV and AIDS (UNAIDS) tahun 2018, lebih dari 500.000 wanita di dunia terserang kanker serviks setiap tahun dan mengakibatkan separuhnya meninggal dunia. Kanker serviks merupakan kanker terbanyak kedua di Indonesia yang memerlukan tindakan/ intervensi kesehatan masyarakat dalam bentuk program penanggulangan nasional (Peraturan Menteri Kesehatan No.34, 2015). Dari data GLOBOCAN, pada tahun 2018 kasus kanker serviks di Indonesia berkisar 32.469 kasus $(17,2 \%)$ dengan angka kematian 18.279 (8,8\%) (GLOBOCAN,2018). Sedangkan untuk data tahun 2020 GLOBOCAN menyebutkan kasus kanker serviks di Indonesia meningkat menjadi 36.633 kasus (GLOBOCAN, 2020).

Informasi mengenai kanker serviks masih kurang dipahami oleh sebagian besar wanita usia produktif di Indonesia. Hal ini sangat memprihatinkan mengingat kanker serviks merupakan salah satu kanker yang dapat dicegah sejak dini (Kementrian Kesehatan RI, 2017).Penanggulangan kanker leher rahim juga dapat dilakukan dengan pencegahan sekunder berupa deteksi dini (skrinning dan edukasi) dan pengobatan segera. (Peraturan Menteri Kesehatan RI No.34 Tahun 2015). Salah satu pemeriksaan deteksi dini kanker serviks adalah dengan pemeriksaan IVA (Inspeksi Visual Asam asetat) yaitu pemeriksaan leher rahim secara visual menggunakan asam cuka, IVA bearti melihat leher rahim dengan mata telanjang untuk mendeteksi abnormalitas setelah pengolesan asam asetat atau cuka (3-5\%). Daerah yang tidak normal akan berubah warna dengan batas yang tegas menjadi putih (acetowhite) yang disebut IVA positif. Hasil IVA positif mengidentifikasikan bahwa leher rahim mungkin memiliki lesi prakanker atau pertanda adanyakelainan pada serviks (Kementrian Kesehatan RI, 2014).

Pemeriksaan IVA merupakan salah satu pelayanan skrining faktor resiko pada standar pelayanan kesehatan usia produktif dengan target capaian harus $100 \%$ (Peraturan Menteri Kesehatan RI Nomor 4, 2019). Berdasarkan Data dari Kementrian Kesehatan Ditjen Program Pencegahan Penyakit (P2P) tahun2019, presentase pemeriksaan deteksi dini kanker leher rahim melalui metode Inspeksi Visual Asam Asetat (IVA) pada perempuan usia 30-50 tahun di Indonesia sampai dengan tahun 2019 di Indonesia sebesar 12, 2\%. Presentase pemeriksaan Inspeksi Visual Asam Asetat (IVA) pada perempuan usia 30-50 tahun di Sumatera Selatan sampai dengan tahun2019 sebesar 20,0\% (Profil Kesehatan Indonesia, 2019). 
Berdasarkan data Dinas Kesehatan kota PalembangTahun 2020 WUS yang melakukan pemeriksaan IVA sebanyak $5846(2,17 \%)$ sedangkan di Puskesmas Taman Bacaan WUS yang melakukan pemeriksaan IVA hanya sebanyak 156 orang (1,74\%). Capaian ini jauh dibawah target dimana Pemeriksaan IVA merupakan salah satu pelayanan skrining faktor resiko pada standar pelayanan kesehatan usia produktif dengan target capaian harus $100 \%$ (Peraturan Menteri Kesehatan RI Nomor 4, 2019).

Beberapa faktor yang dimungkinkan dapat mempengaruhi kunjungan deteksi dini kanker serviks, yaitu presdispossing factor (tingkat pendidikan, pengetahuan, sikap, faktor resiko kanker serviks) enabling factor (akses informasi, keterjangkauan jarak, kesertaan jaminan kesehatan) dan reinforcing factor (dukungan petugas kesehatan, dukungan anggota keluarga, dan dukungan kader kesehatan) (Nordianti dan Bambang, 2018).

Berdasarkan penelitian yang dilakukan oleh Sri Mularsih (2017) menunjukkan bahwa ada hubungan pendidikan dengan minat wanita pasangan usia subur dalam pemeriksaan IVA di Kelurahan Kandri Kecamatan Gunungpati Kota Semarang dengan hasil uji nilai $p$ value 0,00 dimana nilai $p$ value lebih kecil dari $0,05(0,014<$ 0,05).Menurut penelitian Sry Arina Manihuruk,dkk (2019) disebutkan bahwa variable yang paling mempengaruhi perilaku dalam pelaksanaan tes IVA adalah sumber informasi dengan nilai $p$ value 0,000 lebih kecil dari 0,05. Berdasarkan penelitian yang dilakukan oleh Mursita Eka Nordianti dan Bambang Waluyo (2017) menunjukkan bahwa terdapat hubungan antara peran kader kesehatan dengan kunjungan pemeriksaan iva $(p=0,000)$. Tujuan dari penelitian ini adalah untuk mengetahui hubungan tingkat pendidikan, akses informasi dan dukungan kader dengan perilaku pemeriksaan Inspeksi Visual Asam Asetat (IVA) pada Wanita Usia Subur (WUS) di Puskesmas Taman Bacaan Kota Palembang.

\section{METODE PENELITIAN}

Jenis penelitian yang dilakukan adalah penelitian kuantitatif, menggunakan desain penelitian analitik dengan cara pendekatan Cross Sectional dimana variabel independen (tingkat pendidikan, akses informasi dan dukungan kader) dan variabel dependen (perilaku pemeriksaan IVA) diteliti secara bersamaan (Notoatmodjo, 2012). Penelitian ini dilakukan di Puskesmas Taman Bacaan Jl.KH.Azhari Lorong Taman Bacaan Kelurahan Tangga Takat Kecamatan Seberang Ulu II Kota Palembang. Penelitian ini dilaksanakan pada bulan Juni sampai dengan Agustus 2021.

Populasi dalam penelitian ini adalah seluruh Wanita Usia Subur (WUS) usia 3050 tahun yang ada di Puskesmas Taman Bacaan Kota Palembang dari bulan JanuariJuni 2021 yaitu 1652 responden. Pengambilan sampel dilakukan dengan cara non-random sampling dengan teknik accidental sampling, dimana pengambilan sampel ini dilakukan dengan mengambil kasus responden yang kebetulan ada atau tersedia pada saat dilaksanakan penelitian. Jumlah sampel yang diperoleh sebanyak 50 responden.Data primer pada penelitian yaitu data yang diambil langsung dengan melakukan wawancara langsung kepada responden yang berkunjung ke Puskesmas Taman Bacaan Kota Palembang dengan menggunakan kuesioner sebagai alat bantu pengumpulan data.

Analisis data menggunakan analsiis univariat dan analisis bivariat, Analisis bivariat digunakan untuk memperoleh gambaran distribusi frekuensi dan presentase dari semua variabel penelitian, yaitu tingkat 
pendidikan, akses informasi, dukungan kader (variabel independen), dan perilaku pemeriksaan Inspeksi Visual Asam Asetat (IVA) (variabel dependen) (Notoatmodjo, 2012). Sedangkan analisi multivariate digunakan untuk mengetahui hubungan antara variabel independen dengan variabel dependen menggunakan uji statistik Chi Square. Batas kemaknaan yang digunakan dalam penelitian ini adalah $\alpha=0,05$. Pengambilan keputusan statistik dengan ketentuan (Notoatmodjo, 2012) :Bila $p$ value $\leq$ nilai $\alpha(0,05)$, maka ada hubungan antara variabel independen dengan variabel dependen.Bila $p$ value $>$ nilai $\alpha(0,05)$, maka tidak ada hubungan antara variabel independen dengan variabel dependen.

\section{HASIL PENELITIAN}

Hasil penelitian disajikan dalam bentuk Analisis univariat dan bivariat. Analisis univariat dalam penelitian ini akan menggambarkan distribusi frekuensi dari seluruh variable yaitu perilaku pemeriksaan Inspeksi Visual Asam Asetat (IVA), tingkat pendidikan, akses informasi dan dukungan kader.

\section{a. Analisis Univariat}

\section{Tabel 1 Hasil Univariat}

\begin{tabular}{lcc}
\hline Variabel & Frekuensi & Persentase \\
\hline $\begin{array}{l}\text { Perilaku } \\
\text { Pemeriksaan IVA }\end{array}$ & & \\
\hline Ya & 13 & $26 \%$ \\
\hline Tidak & 37 & $74 \%$ \\
\hline & & \\
\hline $\begin{array}{l}\text { Tingkat } \\
\text { Pendidikan }\end{array}$ & & \\
\hline Tinggi & 23 & $46 \%$ \\
\hline Rendah & 27 & $54 \%$ \\
\hline Akses Informasi & & \\
\hline Ya & 19 & $38 \%$ \\
\hline Tidak & 31 & $62 \%$ \\
\hline
\end{tabular}

Dukungan Kader

\begin{tabular}{lcc} 
Ya & 9 & $18 \%$ \\
\hline Tidak & 41 & $82 \%$ \\
\hline
\end{tabular}

Berdasarkan tabel 1 dari 50 responden, yang melakukan pemeriksaan IVA sebanyak 13 orang (26\%) lebih sedikit dari responden yang tidak melakukan pemeriksaan IVA yaitu sebanyak 37 orang (74\%). Respondenyang berpendidikan tinggi sebanyak 23 orang (46\%) lebih sedikit dari responden yang berpendidikan rendah yaitu sebanyak 27 orang (54\%). Respondenyang mendapat akses informasi tentang IVA sebanyak 19 orang (38\%) lebih sedikit dari responden yang tidak mendapat akses informasi tentang IVA yaitu sebanyak 31 orang (62\%), sedangkan respondenyang mendapat dukungan kader sebanyak 9 orang (18\%) lebih sedikit dari responden yang tidak mendapat dukungan kader yaitu sebanyak 41 orang $(82 \%)$.

\section{b. AnalisisBivariat}

Analisa bivariat digunakan untuk mengetahui hubungan antara variabel independen (tingkat pendidikan, akses informasi dan dukungan kader) dengan variabel dependen (perilaku pemeriksaan

Inspeksi Visual Asam Asetat (IVA)).Uji statistik yang digunakan adalah uji ChiSquare dengan program SPSS versi 23.0 dengan menggunakan batas kemaknaan atau nilai $\alpha=0,05$ dan $\mathrm{df}=1$, jika $p$ value $\leq 0,05$ bearti ada hubungan yang bermakna antara variabel independen dengan variabel dependen dan jika $p$ value $>0,05$ bearti tidak ada hubungan antara variabel independen dengan variabel dependen. 
Tabel 2 Hasil Bivariat Hubungan Tingkat Pendidikan, Akses Informasi dan Dukungan Kader dengan Perilaku Pemeriksaan Inspeksi Visual Asam Asetat (IVA)

\begin{tabular}{|c|c|c|c|c|c|c|c|c|c|}
\hline \multirow[t]{3}{*}{ Variabel } & \multirow{3}{*}{$\begin{array}{l}\text { Hasil } \\
\text { ukur }\end{array}$} & \multicolumn{4}{|c|}{ Perilaku pemeriksaan IVA } & \multirow{2}{*}{\multicolumn{2}{|c|}{ Total }} & \multirow{3}{*}{$\begin{array}{c}\text { P- } \\
\text { Value }\end{array}$} & \multirow[t]{3}{*}{ OR $(95 \% \mathrm{CI})$} \\
\hline & & \multicolumn{2}{|c|}{ Ya } & \multicolumn{2}{|c|}{ Tidak } & & & & \\
\hline & & Jumlah & $\%$ & Jumlah & $\%$ & Jumlah & $\%$ & & \\
\hline \multirow{2}{*}{$\begin{array}{c}\text { Tingkat } \\
\text { Pendidikan }\end{array}$} & Tinggi & 10 & 43,5 & 13 & 56,5 & 23 & 100 & \multirow[t]{2}{*}{0,023} & 6,154 \\
\hline & Rendah & 3 & 11,1 & 24 & 89,9 & 27 & 100 & & $\begin{array}{l}(1,435- \\
26,395)\end{array}$ \\
\hline \multirow{2}{*}{$\begin{array}{c}\text { Akses } \\
\text { Informasi }\end{array}$} & $\mathrm{Ya}$ & 12 & 63,2 & 7 & 36,8 & 19 & 100 & \multirow[t]{2}{*}{0,000} & 51,429 \\
\hline & Tidak & 1 & 3,2 & 30 & 96,8 & 31 & 100 & & $\begin{array}{c}(5,701- \\
463,976)\end{array}$ \\
\hline \multirow{2}{*}{$\begin{array}{c}\text { Dukungan } \\
\text { Kader }\end{array}$} & Ya & 8 & 88,9 & 1 & 11,1 & 9 & 100 & \multirow[t]{2}{*}{0,000} & 57,600 \\
\hline & Tidak & 5 & 12,2 & 36 & 87,8 & 41 & 100 & & $\begin{array}{c}(5,894- \\
562,919)\end{array}$ \\
\hline
\end{tabular}

Hasil analisis hubungan antara tingkat pendidikan dengan perilaku pemeriksaan IVA dari 23 responden yang berpendidikan tinggi ada 10 responden $(43,5 \%)$ yang melakukan pemeriksaan IVA dan 13 responden $(56,5 \%)$ yang tidak melakukan pemeriksaan IVA. Sedangkan dari 27 responden yang berpendidikan rendah yang melakukan pemeriksaan IVA ada 3 responden $(11,1 \%)$ dan 24 responden $(89,9 \%)$ yang tidak melakukan pemeriksaan IVA.

Hasil uji Chi-Square diperoleh $p$ value $0,023<\alpha=0,05$, artinya ada hubungan antara tingkat pendidikan secara parsial dengan perilaku pemeriksaan Inspeksi Visual Asam Asetat pada Wanita Usia Subur (WUS) di Puskesmas Taman Bacaan Tahun 2021, sehingga hipotesis yang menyatakan bahwa ada hubungan antara tingkat pendidikan secara parsial dengan perilaku pemeriksaan Inspeksi Visual Asam Asetat terbukti secara statistik.

Dari hasil analisis diperoleh pula nilai Odds Ratio $(\mathrm{OR})=16,154$ (95\%CI : 1,43526,395), artinya Wanita Usia Subur (WUS) dengan tingkat pendidikan rendah mempunyai resiko 16,154 kali untuk tidakmelakukan pemeriksaan IVA dibandingkan dengan Wanita Usia Subur
(WUS) dengan tingkat pendidikan rendah yang melakukan pemeriksaan IVA.

Hasil analisis hubungan antara akses informasi dengan perilaku pemeriksaan IVA bahwa dari 19 responden yang mendapat akses informasi tentang IVA ada 12 responden $(63,2 \%)$ yang melakukan pemeriksaan IVA dan 7 responden $(36,8 \%)$ yang tidak melakukan pemeriksaan IVA. Sedangkan dari 31 responden yang tidak mendapat informasi tentang IVA yang melakukan pemeriksaan IVA ada 1 responden $(3,2 \%)$ dan 30 responden $(96,8 \%)$ yang tidak melakukan pemeriksaan IVA.

Hasil uji Chi-Square diperoleh $p$ value $0,000<\alpha=0,05$, artinya ada hubungan antara akses informasi secara parsial dengan perilaku pemeriksaan Inspeksi Visual Asam Asetat pada Wanita Usia Subur (WUS) di Puskesmas Taman Bacaan Tahun 2021, sehingga hipotesis yang menyatakan bahwa ada hubungan antara akses informasi secara parsial dengan perilaku pemeriksaan Inspeksi Visual Asam Asetat terbukti secara statistik.

Dari hasil analisis diperoleh pula nilai Odds Ratio $(\mathrm{OR})=51,429(95 \% \mathrm{CI}: 5,701-$ 463,976), artinya Wanita Usia Subur (WUS) yang tidak mendapat akses informasi tentang IVA mempunyai resiko 51,429 kali untuk tidak melakukan pemeriksaan IVA 
dibandingkan dengan Wanita Usia Subur (WUS) yang tidak mendapat akses informasi tentang IVA dan melakukan pemeriksaan IVA.

Hasil analisis hubungan antara akses informasi dengan perilaku pemeriksaan IVA bahwa dari dari 9 responden yang mendapat dukungan kader ada 8 responden $(88,9 \%)$ yang melakukan pemeriksaan IVA dan 1 responden $(11,1 \%)$ yang tidak melakukan pemeriksaan IVA. Sedangkan dari 41 responden yang tidak mendapat dukungan kader yang melakukan pemeriksaan IVA ada 5 responden $(12,2 \%)$ yang melakukan pemeriksaan IVA dan 36 responden $(87,8 \%)$ yang tidak melakukan pemeriksaan IVA.

Hasil uji Chi-Square diperoleh $p$ value $0,000<\alpha=0,05$, artinya ada hubungan antara dukungan kader secara parsial dengan perilaku pemeriksaan Inspeksi Visual Asam Asetat pada Wanita Usia Subur (WUS) di Puskesmas Taman Bacaan Tahun 2021, sehingga hipotesis yang menyatakan bahwa ada hubungan antara dukungan kader secara parsial dengan perilaku pemeriksaan Inspeksi Visual Asam Asetat terbukti secara statistik.

Dari hasil analisis diperoleh pula nilai Odds Ratio (OR) = 57,600 (95\%CI : 5,894562,919 ), artinya Wanita Usia Subur (WUS) yang tidak mendapat dukungan kader mempunyai resiko 57,600 kali untuk tidakmelakukan pemeriksaan IVA dibandingkan dengan Wanita Usia Subur (WUS) yang tidak mendapat dukungan kader dan melakukan pemeriksaan IVA.

\section{PEMBAHASAN}

Pembahasan hasil penelitian ini menguraikan tentang hasil penelitian dengan konsep terkait dan hasil penelitian terdahulu. Hasil penelitian ini secara umum sudah menjawab pertanyaan sesuai dengan tujuan penelitian yaitu untuk mengetahui hubungan tingkat pendidikan, akses informasi dan dukungan kader dengan perilaku pemeriksaan Inspeksi Visual Asam Asetat pada Wanita Usia Subur di Puskesmas Taman Bacaan Kota Palembang Tahun 2021, setelah dilakukan uji statistik bivariat diperoleh sebagai berikut:

\section{Tingkat Pendidikan}

Hasil analisis univariat menunjukkan dari 50 responden, yang berpendidikan tinggi sebanyak 23 orang $(46 \%)$ lebih sedikit dari responden yang berpendidikan rendah yaitu sebanyak 27 orang (54\%). Hasil analisis bivariatmenunjukkan bahwa dari 23 responden yang berpendidikan tinggi ada 10 responden $(43,5 \%)$ yang melakukan pemeriksaan IVA dan 13 responden $(56,5 \%)$ yang tidak melakukan pemeriksaan IVA. Sedangkan dari 27 responden yang berpendidikan rendah yang melakukan pemeriksaan IVA ada 3 responden $(11,1 \%)$ dan 24 responden $(89,9 \%)$ yang tidak melakukan pemeriksaan IVA.

Hasil uji Chi-Square diperoleh $p$ value $0,023<\alpha=0,05$, artinya ada hubungan antara tingkat pendidikan secara parsial dengan perilaku pemeriksaan Inspeksi Visual Asam Asetat pada Wanita Usia Subur (WUS) di Puskesmas Taman Bacaan Tahun 2021, sehingga hipotesis yang menyatakan bahwa ada hubungan antara tingkat pendidikan secara parsial dengan perilaku pemeriksaan Inspeksi Visual Asam Asetat terbukti secara statistik.

Dari hasil analisis diperoleh pula nilai Odds Ratio $(\mathrm{OR})=16,154$ (95\%CI : 1,43526,395), artinya Wanita Usia Subur (WUS) dengan tingkat pendidikan rendah mempunyai resiko 16,154 kali untuk tidakmelakukan pemeriksaan IVA dibandingkan dengan Wanita Usia Subur (WUS) dengan tingkat pendidikan rendah yang melakukan pemeriksaan IVA.

Hasil penelitian ini sejalan dengan teori semakin tinggi tingkat pendidikan yang dimiliki seseorang maka semakin luas wawasan dan pengetahuan yang diperoleh (Nototmodjo, 2003 dalam Mularsih, 2017). Dengan demikian dapat diartikan bahwa semakin tinggi pendidikan sesorang, maka makin mudah untuk menerima informasi sehingga makin banyak pula pengetahuan yang dimilikinya, (Priyoto, 2019). Kurangnya pengetahuan masyarakat mengenai pelayanan kesehatan akan mempengaruhi pemanfaatan fasilitas kesehatan yang ada sehingga berpengaruh pada kondisi kesehatan mereka. 
Pendidikan bertujuan untuk memerangi kebodohan, dapat berpengaruh terhadap peningkatan kemampuan berusaha, sehingga dapat meningkatkan pendapatan. Selanjutnya akan dapat meningkatkan kemampuan untuk memelihara dan meningkatkan kesehatannya. (Notoatmodjo, 2012).

Penelitian ini sejalan dengan penelitian yang dilakukan oleh Sri Mularsih dengan judul "Faktor-faktor yang Berhubungan dengan Minat Wanita Pasangan Usia Subur Dalam Pemeriksaan Inspeksi Visual Asam Asetat (IVA) di Kelurahan Kandri Kecamatan Gunungpati Kota Semarang Tahun 2017" menunjukkan bahwa ada hubungan pendidikan dengan minat wanita pasangan usia subur dalam pemeriksaan IVA di Kelurahan Kandri Kecamatan Gunungpati Kota Semarang dengan hasil uji nilai $p$ value 0,00 dimana nilai $p$ value lebih kecil dari 0,05 $(0,014<0,05)$.

Penelitian ini juga sejalan dengan penelitian yang dilakukan Rahmita Ayu lestari yang berjudul "Faktor-faktor yang Berhubungan dengan Perilaku Deteksi Dini Kanker Serviks Menggunakan Metode Inspeksi Visual Asam Asetat (IVA) pada Pasangan Usia Subur di Wilayah Puskesmas Kelurahan Kemanggisan Kecamatan Palmerah Jakarta Barat Tahun 2016" juga menunjukkan ada hubungan antara tingkat pendidikan dengan perilaku deteksi dini kanker serviks menggunakan metode Inspeksi Visual Asam Asetat (IVA) dengan nilai $p$ value 0,003 .

Kesimpulan yang sama juga diperoleh penelitian Sri Dewi Handayani, Dyah Noviawati Setya Arum dan Nanik Setiyawati yang berjudul "Faktor-faktor yang Mempengaruhi Perilaku Pemeriksaan IVA pada Wanita Usia Subur di Desa Penyak Kecamatan Koba Kabupaten Bangka Tengah Tahun 2017" sebagian besar responden memiliki pendidikan yang masih rendah (SD dan SMP). Banyaknya jumlah responden yang memiliki pendidikan rendah yang tidak melakukan pemeriksaan IVA $(88,1 \%)$ menunjukkan bahwa sebagian besar responden kurang menyadari akan pentingnya pendidikan untuk menjadi jembatan dalam memperoleh informasi. Hasil $p$ value $=0,003$ menunjukkan terdapat hubungan yang signifikan antara pendidikan dengan perilaku pemeriksaan IVA.

Dari hasil penelitian, teori dan penelitian terkait peneliti berasumsi bahwa semakin tinggitingkat pendidikan yang dimiliki seseorang maka semakin luas wawasan dan pengetahuan yang dimilikinya. Pengetahuan yang luas tersebut akan mempengaruhi perilaku sehari-hari termasuk perilaku kesehatan.

\section{Akses Informasi}

Hasil analisis univariat dari 50 responden, yang mendapat akses informasi tentang IVA sebanyak 19 orang $(38 \%)$ lebih sedikit dari responden yang tidak mendapat akses informasi tentang IVA yaitu sebanyak 31 orang (62\%). Hasil analisis bivariatmenunjukkan bahwadari 19 responden yang mendapat akses informasi tentang IVA ada 12 responden $(63,2 \%)$ yang melakukan pemeriksaan IVA dan 7 responden $(36,8 \%)$ yang tidak melakukan pemeriksaan IVA. Sedangkan dari 31 responden yang tidak mendapat informasi tentang IVA yang melakukan pemeriksaan IVA ada 1 responden $(3,2 \%)$ an melakukan pemeriksaan IVA dan 30 responden $(96,8 \%)$ yang tidak melakukan pemeriksaan IVA.

Hasil uji Chi-Square diperoleh $p$ value $0,000<\alpha=0,05$, artinya ada hubungan antara akses informasi secara parsial dengan perilaku pemeriksaan Inspeksi Visual Asam Asetat pada Wanita Usia Subur (WUS) di Puskesmas Taman Bacaan Tahun 2021, sehingga hipotesis yang menyatakan bahwa ada hubungan antara akses informasi secara parsial dengan perilaku pemeriksaan Inspeksi Visual Asam Asetat (IVA) terbukti secara statistik.

Dari hasil analisis diperoleh pula nilai Odds Ratio (OR) $=51,429$ (95\%CI : 5,701 463,976), artinya Wanita Usia Subur (WUS) yang tidak mendapat akses informasi tentang IVA mempunyai resiko 51,429 kali untuk tidak melakukan pemeriksaan IVA dibandingkan dengan Wanita Usia Subur (WUS) yang tidak mendapat akses informasi 
tentang IVA dan melakukan pemeriksaan IVA.

Hasil penelitian ini sejalan dengan teori bahwa di dalam program-program kesehatan, agar diperoleh perubahan perilaku yang sesuai dengan norma-norma kesehatan, sangat diperlukan usaha-usaha konkret dan positif. Salah satu strategi untuk memperolah perubahan perilaku tersebut oleh World Health Organization (WHO) adalah pemberian informasi. Dengan memberikan informasi-informasi tentang cara-cara mencapai hidup sehat, cara pemeliharaan kesehatan, cara menghindari penyakit, dan sebagainya akan meningkatkan pengetahuan masyarakat tentang hal tersebut. Selanjutnya dengan pengetahuan-pengetahuan itu akan menimbulkan kesadaran mereka, dan akhirnya akan menyebabkan orang berperilaku sesuai dengan pengetahuan yang dimilikinya itu. (Notoatmodjo, 2012). Informasi adalah data-data yang telah diolah sehingga dapat berguna bagi siapa saja yang membutuhkan. Informasi bisa dikatakan sebagai pengetahuan yang didapatkan dari belajar, pengalaman atau instruksi (Priyoto, 2019).

Pemberian informasi tentang pemeriksaan Inpeksi Visual Asam Asetat (IVA) dapat dilakukan dengan kegiatan promosi dan edukasi melalui penyuluhan petugas kesehatan dan penyuluhan kader posyandu. Pemberian informasi dapat juga dilakukan dengan sosialisasi melalui berbagai media seperti televisi, radio, internet, broaur, poster, leaflet, majalah dan koran. Media yang digunakan diharapkan untuk memperluas cakupan informasi kepada masyarakat luas (Kementrian Kesehatan RI, 2015).

Penelitian ini sejalan dengan penelitian Riri Maharani dan Chikma Vitria Syah tahun 2017 yang berjudul“" Perilaku Deteksi Dini Kanker Serviks dengan Pemeriksaan IVA oleh Wanita Usia Subur (WUS) di Desa Sorek Satu Wilayah Kerja Puskesmas Pangkalan Kuras Kabupaten Pelalawan" dimana hasil uji statitistik diperoleh P-value 0,045 menunjukkan ada hubungan yang signifikan antara media informasi terhadap perilaku deteksi dini kanker serviks dengan pemeriksaan IVA. Penelitian ini juga sejalan dengan penelitian Kartika Adyani dan Friska Realita tahun 2020 yang berjudul "Factors that Influence the Participation Among Women in Inspection Visual Acetic Acid (IVA) Test" menunjukkan ada hubungan yang siginifikan antara akses informasi dan partisipasi dalam pemeriksaan IVA di wilayah kerja Puskesmas Cepiring Kendal dengan hasil Pvalue 0,007.

Kesimpulan yang sama juga diperoleh penelitian Widia Nisa, Rapael Ginting dan Ermi Girsang tahun 2018 yang berjudul "Faktor yang Mempengaruhi Pemanfaatan Inspeksi Visual Asam Asetat (IVA) pada Wanita Usia Subur di Wilayah Kerja Puskesmas Mandala Kecamatan Medan Tembung Kota Medan" hasil uji statistik menggunakan uji chi-square diperoleh $P$ value $=0,000$. Hasil ini menunjukkan ada hubungan yang signifikan antara informasi dalam deteksi dini kanker serviks dengan metode pemeriksaan IVA.

Dari hasil penelitian, teori dan penelitian terkait peneliti berasumsi bahwa semakin banyak informasi yang diterima oleh seseorang tentang pemeriksaan IVA, maka orang tersebut berpeluang lebih besar untuk melakukan pemeriksaan IVA.

\section{Dukungan Kader}

Hasil analisis univariat menunjukkan dari 50 responden, yang mendapat dukungan kader sebanyak 9 orang (18\%) lebih sedikit dari responden yang tidak mendapat dukungan kader yaitu sebanyak 41 orang $(82 \%)$. Hasil analisis bivariatmenunjukkan dari 9 responden yang mendapat dukungan kader ada 8 responden $(88,9 \%)$ yang melakukan pemeriksaan IVA dan 1 responden $(11,1 \%)$ yang tidak melakukan pemeriksaan IVA. Sedangkan dari 41 responden yang tidak mendapat dukungan kader yang melakukan pemeriksaan IVA ada 5 responden $(12,2 \%)$ yang melakukan pemeriksaan IVA dan 36 responden $(87,8 \%)$ yang tidak melakukan pemeriksaan IVA.

Hasil uji Chi-Square diperoleh $p$ value $0,000<\alpha=0,05$, artinya ada hubungan antara dukungan kader secara parsial dengan 
perilaku pemeriksaan Inspeksi Visual Asam Asetat pada Wanita Usia Subur (WUS) di Puskesmas Taman Bacaan Tahun 2021, sehingga hipotesis yang menyatakan bahwa ada hubungan antara dukungan kader secara parsial dengan perilaku pemeriksaan Inspeksi Visual Asam Asetat terbukti secara statistik.

Dari hasil analisis diperoleh pula nilai Odds Ratio $(\mathrm{OR})=57,600$ (95\%CI : 5,894562,919 ), artinya Wanita Usia Subur (WUS) yang tidak mendapat dukungan kader mempunyai resiko 57,600 kali untuk tidakmelakukan pemeriksaan IVA dibandingkan dengan Wanita Usia Subur (WUS) yang tidak mendapat dukungan kader dan melakukan pemeriksaan IVA.

Hasil penelitian ini sejalan dengan teori bahwa Di bidang kesehatan, pemberdayaan masyarakat adalah upaya atau proses untuk menumbuhkan kesadaran, kemauan dan kemampuan dalam memelihara dan meningkatkan kesehatan (Notoatdmodjo, 2012). Kader pemberdayaan masyarakat bidang kesehatan yang selanjutnya disebut kader kesehatan adalah setiap orang yang dipilih oleh masyarakat dan dilatih untuk menggerakkan masyarakat berpartisipasi dalam pemberdayaan masyarakat bidang kesehatan . Dukungan kader kesehatan dalam pemeriksaan Inspeksi Visual Asam Asetat (IVA) dapat berupa: memberikan penyuluhan, mengajak wanita usia subur (WUS) untuk melakukan pemeriksaan IVA dan menjemput/ mengantar WUS untuk melakukan pemeriksaan IVA (Peraturan Menteri Kesehatan RI No.8 Tahun 2019).

Hasil penelitian ini sejalan dengan penelitian Ayu Wulandari, Sri Wahyuningsih dan Ferdiana Yunita yang berjudul "Faktorfaktor yang Berhubungan dengan Perilaku Pemeriksaan Inspeksi Visual Asam Asetat (IVA) pada Wanita Usia Subur (WUS) di Puskemas Sukmajaya Tahun 2016 dimana hasil uji statistik menggunakan uji chi-square diperoleh $P$ value $=0,037$, hasil ini menunujukkan bahwa terdapat hubungan yang signifikan antara dukungan kader kesehatan dengan perilaku pemeriksaan IVA di Puskesmas Sukmajaya. Hasil penelitian ini juga sejalan dengan penelitian Mursita Eka
Nordianti dan Bambang Waluyo tahun 2018 yang berjudul "Determinan Kunjungan Inspeksi Visual Asam Asetat di Puskesmas Kota Semarang" dimana hasil uji statistik menggunakan uji chi-square diperoleh $P$ value $=0,000$ menunjukkan bahwa terdapat hubungan antara peran kader kesehatan dengan kunjungan pemeriksaan IVA di Puskesmas Kota Semarang.

Kesimpulan yang sama juga diperoleh penelitian Sri Dewi Handayani, Dyah Noviawati Setya Arum dan Nanik Setiyawati yang berjudul "Faktor-faktor yang Mempengaruhi Perilaku Pemeriksaan IVA pada Wanita Usia Subur di Desa Penyak Kecamatan Koba Kabupaten Bangka Tengah Tahun 2017" dimana hasil $P$ value $=0,001$ menunjukkan bahwa terdapat hubungan antara dukungan kader kesehatan dengan kunjungan pemeriksaan IVA di di desa Penyak tahun 2017.

Dari hasil penelitian, teori dan penelitian terkait peneliti berasumsi bahwa semakin besar dukungan yang diberikan oleh kader kepada Wanita Usia Subur (WUS) baik berupa penyuluhan tentang pemeriksaan IVA ataupun berupa ajakan untuk melakukan pemeriksaan IVA, maka semakin besar peluang Wanita Usia Subur (WUS) untuk melakukan pemeriksaan IVA.

\section{KESIMPULAN}

Berdasarkan penelitian yang dilakukan,diperoleh dari hasil penelitian telah sesuai dengan tujuan khusus yaitu mengetahui hubungan tingkat pendidikan, akses informasi dan dukungan kader dengan perilaku pemeriksaan Inspeksi Visual Asam Asetat (IVA) pada Wanita Usia Subur (WUS) di Puskesmas Taman Bacaan kota Palembang tahun 2021. Berdasarkan hubungan dari masing-masing variabel yang diteliti, maka penulis mengambil kesimpulan bahwa tingkat pendidikan. Akses informasi dan dukungan kader memiliki hubungan yang bermakna dengan perilaku pemeriksaan IVA.

\section{DAFTAR PUSTAKA}


Adyani, Kartika dan Friska Realita. 2020. Factors That Influence The Participation Among Women In Inspection Visual Acetic acid (IVA) Test. Semarang: UNISSULA.

Dinas Kesehatan Kota Palembang. 2018. Profil Dinas Kesehatan Kota Palembang Tahun 2018. Palembang.

Dinas Kesehatan Kota Palembang. 2019. Laporan Tahunan Seksi Penyakit Tidak Menular. Palembang.

Dinas Kesehatan Kota Palembang. 2020. Laporan Tahunan Seksi Penyakit Tidak Menular. Palembang.

Handayani, SR, Dyah N, Setya A, Nanik S. 2017. Faktor-faktor yang Mempengaruhi Pemeriksaan IVA pada Wanita Usia Subur di Desa Penyak Kecamatan Koba Kabupaten Bangka Tengah Tahun 2017. Jurusan Kebidanan Poltekkes Kemenkes Yogyakarta.

Indrawati, ND, Dewi P, dan Indri,AP. 2018 Lesi Prakanker Wanita Usia Subur. Universitas Muhammadiyah Semarang.

Junaidi, Iskandar dan Frisca Melissa. 2020. Panduan Lengkap Kanker Serviks. Jakarta: Rapha Publishing.

Kementerian Kesehatan RI. 2014. Panduan Layanan Integrasi Infeksi Saluran Reproduksil Infeksi Menular Seksual (ISR/IMS)/ Deteksi Dini Kanker Leher Rahim dengan Inspesksi Visual Asam ASetat (IVA), dan Deteksi Dini Kanker Payudara. Jakarta.

Kementrian Kesehatan RI. 2015. Deteksi Dini Kanker Payudara dan Kanker Leher Rahim. Jakarta.

Kementrian Kesehatan RI. 2017. Pedoman Pelayanan Kedokteran Kanker Serviks. Jakarta: Komite Penanggualangan Kanker Nasional.
Kementerian Kesehatan RI. 2017. Kanker Serviks. Jakarta.

Kementerian Kesehatan RI. 2019. Beban Kanker di Indonesia. Jakarta.

Kementrian Kesehatan RI. 2019. Profil Kesehatan Indonesia Tahun 2019. Jakarta. Lestari, Ayu. 2016. Faktor-faktor yang Berhubungan dengan Perilaku Deteksi Dini Kanker Serviks Menggunakan Metode Inspeksi Visual Asam Asetat (IVA) pada Pasangan Usia Subur di Wilayah Puskesmas Kelurahan Kemanggisan Kecamatan Palmerah. Jakarta Barat Tahun 2016. Fakultas Ilmu Kesehatan Universeitas Esa Unggul.

Maharani,R dan Chikma VT. 2019. Perilaku Deteksi Dini Kanker Serviks dengan Pemeriksaan IVA oleh Wanita Usia Subbur (WUS) di Desa Sorek Satu Wilayah Kerja Puskesmas Pangkalan Kuras Kabupaten Pelalawan. Stikes Hang Tuah Pekanbaru.

Mandang, J, Freike L, Iyam M, Naomy M. 2016. Kesehatan Reproduksi dan Pelayanan Keluarga Berenca (KB). Bogor: In Media.

Masturoh, Imas dan Nauri Anggita. 2018. Metodologi Penelitian Kesehatan. Jakarta: Kementrian Kesehatan RI.

Mularsih, Sri. 2017. Faktor-faktor yang Berhubungan dengan Minat Wanita Pasangan Usia Subur dalam Pemeriksaan Visual Asam Asetat (IVA) di Kelurahan Kandri Kecamatan Gunungjati Kota Semarang. Akademi Kebidanan Abdi Husada Semarang.

Mustika, DN, E.Kusumawati, dan S.Istiana, 2016. Deteksi Dini Kanker Serviks dan Payudara. Semarang: Rafi Sarana Perkasa.

Nisa, W, Rapael G, Ermi G, 2019. Faktor yang Mempengaruhi Pemanfaatan Visual 
Asam Asetat (IVA) pada Wanita Usia Subur di Wilayah Kerja Puskesmas Mandala Kecamatan Medan Tembung Kota Medan. Departemen Ilmu Kesehatan Masyarakat Institut Kesehatan Helvetia.

Nordianti, ME dan Bambang, W. 2017. Determinan Kunjungan Inspeksi Visual Asam Asetat di Puskesmas Kota Semarang. Jurusan Ilmu Kesehatan Masyarakat, Fakultas Ilmu Keolahragaan Universitas Negeri Semarang.

Notoatmodjo, Soekidjo, 2012. Promosi Kesehatan dan Perilaku Kesehatan. Jakarta: Rineka Cipta.

Notoatmodjo, Soekidjo. 2012, Metodologi Penelitian Kesehatan. Jakarta: Rineka Cipta.

Permenkes RI. 2018. Peraturan Menteri Kesehatan Republik Indonesia Nomor 88 Tahun 2014 Tentang Standar Tablet Tambah Darah Bagi Wanita Usia Subur dan Ibu Hamil. Jakarta

Permenkes RI. 2015. Peraturan Menteri Kesehatan Republik Indonesia Nomor 34 Tahun 2015 Tentang Penanggulangan Kanker Payudara dan Kanker Leher Rahim. Jakarta.

Permenkes RI. 2019. Peraturan Menteri Kesehatan Republik Indonesia Nomor 4 Tahun 2019 Tentang Standar teknis Pemenuhan Mutu Pelayanan Dasar Pada Standar Pelayanan Minimal Bidang Kesehatan. Jakarta.

Permenkes RI. 2019. Peraturan Menteri Kesehatan Republik Indonesia Nomor 8 Tahun 2019 Tentang Pemberdayaan Masyarakat Bidang Kesehatan. Jakarta.

Permenkes RI. 2019. Peraturan Menteri Kesehatan Republik Indonesia Nomor 4 Tahun 2019 Tentang Standar teknis Pemenuhan Mutu Pelayanan Dasar Pada
Standar Pelayanan Minimal Bidang Kesehatan. Jakarta.

Priyoto, 2019. Teori Sikap dan Perilau dalam Kesehatan. Yogyakarta: Nuha Medika.

Syafrudin, 2015. Epidemiologi dalam Kebidanan. Bogor: In Media.

Wulandari, A, Sri Wahyuni dan Ferdiana,Y. 2018. Faktor-faktor yang Berhubungan dengan Perilaku Pemeriksaan Inspeksi Visual Asam Asetat (IVA) pada Wanita Usia Subur (WUS) di Puskesmas Sukmajaya Tahun 2016. JK Unila 